\title{
Regulation of heme oxygenase-1 induction during recurrent insulin induced hypoglycemia
}

\author{
Syed Quadri ${ }^{1}$, Priyanka Prathipati ${ }^{1}$, Debra W. Jackson ${ }^{2}$, Keith E. Jackson ${ }^{1 *}$ \\ ${ }^{1}$ Department of Basic Pharmaceutical Sciences, College of Pharmacy, University of Louisiana at Monroe, Monroe, LA 71201. USA \\ ${ }^{2}$ Departments of Biology, College of Arts, Education, and Sciences, University of Louisiana at Monroe, Monroe, LA 71209. USA \\ *Corresponding author E-mail: kjackson@ulm.edu
}

\begin{abstract}
Background: Recurrent insulin induced hypoglycemia (RIIH) is an unavoidable risk of conventional therapeutic management of insulin dependent diabetes mellitus and is a primary cause of impaired glucose counter regulation. Circulating angiotensin II (AngII) has been reported to be elevated in diabetic models, and is linked to the promotion of hypertension.

Objective: The current study was performed to evaluate the hypothesis that chronic insulin injections and/or hypoglycemia promotes hypertension via an increase in AngII, which increases endogenous carbon monoxide (CO) through an induction in heme oxygenase (HO-1).

Methods: Male Sprague Dawley rats $(200-250 \mathrm{~g})$ were treated for 2 weeks with daily injections of $7 \mathrm{U} / \mathrm{kg}$ insulin or diluent. On the $14^{\text {th }}$ day, surgery was performed and rats were administered various doses of captopril $(2 \mathrm{mg} / \mathrm{kg}, 8 \mathrm{mg} / \mathrm{kg}$, and $12 \mathrm{mg} / \mathrm{kg})$ or vehicle. Following the dose evaluation, subsets of previously treated animals were treated with vehicle, DALA $(80 \mu \mathrm{g} / \mathrm{kg})$, Captopril $(12 \mathrm{mg} / \mathrm{kg})$ or a combination of DALA $(80 \mu \mathrm{g} / \mathrm{kg})+$ CAP $(12 \mathrm{mg} / \mathrm{kg})$.

Results: A dose dependent decrease in blood pressure was observed during captopril treatment in RIIH hypertensive rats. However, there was no change in urine output among the treatment groups. Captopril and DALA+CAP treatments produced a reduction in blood pressure as compared to animals treated with DALA alone. Carboxyhemoglobin and AngII concentrations were also reduced in animals treated with captopril and DALA+CAP. In addition, HO-1 protein levels in heart and kidney were reduced when compared to DALA treated animals.

Conclusion: These results demonstrate that RIIH promotes an increase in circulating AngII and hypertension via an induction in HO-1, which significantly increases endogenous CO levels.
\end{abstract}

Keywords: Angiotensin II, Carbon Monoxide, Heme Oxygenase, Recurring Insulin-Induced Hypoglycemia (RIIH).

\section{Introduction}

Diabetes mellitus is marked by elevated levels of blood glucose, which results from defects in insulin production, insulin utilization or both. Insulin dependent diabetes mellitus (IDDM) also known as Type I diabetes presents when the production of insulin in the pancreas is very little or absent, thus an elevation in circulating blood glucose levels ensues. In an attempt to maintain normal circulating blood glucose, diabetic patients are treated with injections of insulin, which often leads to hypoglycemic side effects, such as autonomic dysfunction (Briscoe et al. 2007, Hoffman 2007). Recurrent insulin induced hypoglycemia (RIIH) is an unavoidable risk of insulin therapy in diabetic patients. Hypoglycemia may also be associated with profound changes in hemodynamic function, which includes increases in heart rate, stroke volume, myocardial contractility, and cardiac output (Fisher et al. 1987, Fisher et al. 1990). Alterations in hemodynamic function produced during hypoglycemia could have adverse effects in diabetic patients, including endothelial dysfunction which can promote endorgan damage. Blood glucose was reported as a key contributing factor for the development of diabetic nephropathy, namely hypertension and renal failure (Das Evcimen \& King 2007, Fukami et al. 2007). Many labs have reported an increase in angiotensin II (AngII) levels in diabetic animal models (Eadington et al. 1994,
Harrison-Bernard et al. 2002). It has also been reported that AngII produces glomerular hyperfiltration, which could possibly promote renal failure (Sochett et al. 2006). Controversy currently exist in the literature as it relates to the ability of hypoglycemia to potentially promote hypertension via an elevation in AngII, a direct increase in vascular tone, or through activation of an additional pathway; namely via a decrease in the bioavailability of nitrous oxide (NO) and/or oxidative stress (Brands \& Fitzgerald 2002, Bank et al. 2007).

Carbon monoxide $(\mathrm{CO})$ is rapidly gaining a reputation as a potential modulator of blood pressure (Johnson et al. 1995, Johnson et al. 2002). Endogenous production of CO is mediated by the enzymatic breakdown of heme by the enzyme heme oxygenase (HO). Two major isoform of HO have been reported, the inducible HO-1 and constitutive HO-2 (Maines 1997). It has been reported that both isoforms are present in the kidney (Jackson et al. 2011). Various biological stresses, including oxidative stress, ischemia, and hypertension are known to elevate HO-1 levels (Aizawa et al. 2000, Haugen et al. 2000, Quan et al. 2004 ). However, the HO-2 isoform is constitutively expressed and has been reported to be present in high concentrations in the kidney, as well as in other vascular beds and tissues (Hu et al. 1998). Alterations in HO levels have been demonstrated to alter $\mathrm{CO}$ concentration, in addition to having profound effects on vascular tone (Grundemar et al. 1995, 
Sammut et al. 1998). Pathological conditions (Ferrándiz \& Devesa 2008), such as AngII-induced hypertension, DOCA-salt hypertension (Johnson et al. 2004 ), promote increases in HO-1 expression (Ishizaka et al. 2000, Ferrándiz \& Devesa 2008). In addition, studies conducted in our lab demonstrated that acute infusion of low dose AngII (5ng/kg/hr) and recurrent insulin administration increase HO-1 concentrations in both the heart and kidney (Quadri et al. 2014). Furthermore, an induction of HO-1 has been reported to increase $\mathrm{CO}$ levels during hypertension, which can aggravate oxidative stress and promote end-organ damage.

Current literature supports a relationship between hypertension, induced oxidative stress and an activation in the heme oxygenase system (Botros et al. 2007, Freidja et al. 2011). Also, AngII induction of HO-1 leads to an increase in endogenous $\mathrm{CO}$ levels (Aizawa et al. 2000, Li et al. 2004, Quadri et al. 2014). Therefore, the adverse effects of significant increases in endogenously formed $\mathrm{CO}$ levels could be mediated through an induction of the oxidative stress pathway and/or reduction in $\mathrm{NO}$ which has been reported to increase superoxide formation and could be associated with endorgan damage (Jadhav et al. 2008, Freidja et al. 2011). Thus, the regulation of vascular tone by $\mathrm{CO}$ appears to be concentration dependent, where substantial elevations of $\mathrm{CO}$ levels via an increase in $\mathrm{HO}$ activity, produces an inhibition of NOS and contributes to endothelial dysfunction in several models of hypertension (Ndisang et al. 2002, Teran et al. 2005). Alternatively smaller elevations in the concentration of $\mathrm{CO}$ promote a vascular smooth muscle mediated decrease in tone and blood pressure (Leffler et al. 2011, Marazioti et al. 2011). We have recently reported that the observed hypertension during RIIH is mediated via an induction in HO-1 and a significant increase in endogenous CO levels (Quadri et al. 2014). Therefore, the current study was performed to evaluate the hypothesis that the observed hypertension during RIIH is mediated via an increase in AngII, which promotes a significant increase in endogenous $\mathrm{CO}$.

\section{Methods}

\subsection{Chemicals}

DALA was purchased from Frontier Scientific (Logan, UT, USA). Inactin (thiobutabarbital sodium), captopril and paraaminohippuric acid (PAH) were obtained from Sigma-Aldrich (St. Louis, MO, USA). Albumin was purchased from EMD Biosciences Inc. (San Diego, CA, USA). Inulin was purchased from Fresenius Kabi UK Ltd. (Runcorn, Cheshire). Rat HO-1 kits were purchased from Stressgen, Enzo Life Sciences Int'l, Inc (Plymouth Meeting, PA, USA). All other chemicals were purchased from Fisher Scientific (Houston, TX, USA). Vehicle stock solution was prepared in saline on the day of the experiment. All other solutions were freshly prepared on the day of the experiment.

\subsection{Animals}

Male Sprague-Dawley rats (200 - 250g, $n=55$, Harlan, Indianapolis, IN, USA) were used. The following studies were approved by the University of Louisiana at Monroe Institutional Animal Care and Use Committee. Prior to the experiments, rats were housed in a controlled environment and had free access to commercial rat chow and tap water.

For the purpose of this study, we used a recently generated hypoglycemic and/or chronic recurrent insulin rat model, which was first used in studies examining the neurological effect of hypoglycemia (Paranjape \& Briski 2005) and recently used in our lab to study the effects of RIIH on hemodynamic function (Quadri et al. 2014). As previously described, rats were treated for 14 days with $7 \mathrm{U} / \mathrm{Kg}$ subcutaneous injections of humulin insulin (Quadri et al. 2014) to produce a sustained hypoglycemic state and promote hypertension.

\subsection{Acute Surgery}

On the $14^{\text {th }}$ day, rats were anesthetized with a single injection of thiobutabarbital sodium (Inactin, $120 \mathrm{mg} / \mathrm{kg}$ ip) and surgical procedures were performed as described previously (Quadri et al. 2014). Following the surgical procedures, rats were allowed to stabilize for $45 \mathrm{~min}$. After this initial stabilization period, a 30-minute control period was observed, following the control period various doses of captopril $(2 \mathrm{mg} / \mathrm{kg}, 8 \mathrm{mg} / \mathrm{kg}, 12 \mathrm{mg} / \mathrm{kg})$ and DALA $(80 \mu \mathrm{g} / \mathrm{kg})$ were infused intravenously and urine samples were collected.

Blood samples were drawn from the carotid artery for determination of blood glucose levels. Additional blood was collected in EDTA tubes, centrifuged and the plasma was removed from the blood collections. Plasma samples were aliquoted and stored at $20^{\circ} \mathrm{C}$ until analyzed. The heart and kidneys were extracted and stored at $-80^{\circ} \mathrm{C}$ until analyzed.

\subsection{Determination of glomerular filtration rate}

Inulin, para-amino hippuric acid and albumin were administered intravenously during the surgery through the jugular vein. Inulin and $\mathrm{PAH}$ concentrations were measured to determine glomerular filtration rate (GFR) and renal plasma flow, respectively. Flame photometry was used to determine sodium and potassium concentrations in urine and plasma samples.

\subsection{Determination of heme oxygenase protein levels:}

Following the previously delineated acute surgeries, the thoracic and abdominal cavities were opened and the hearts and kidneys were extracted respectively. Opening of the thoracic cavity is an Institutional Animal Care and Use Committee approved method of sacrificing an animal. The extracted hearts and kidneys were snap frozen with liquid nitrogen and stored at $-80^{\circ} \mathrm{C}$ until analyzed for HO- 1 content. HO- 1 levels were measured by commercially available ELISA kits purchased from Stressgen. Briefly, heart and kidneys from vehicle, captopril treated and a combination of DALA and captopril treated rats were extracted, flash frozen in liquid nitrogen and suspended in $1 \mathrm{X}$ extraction reagent, and protease inhibitor. Once the kidney and heart tissues were homogenized, the ELISA sandwich assay was performed and the level of HO-1 present was determined by comparison to a standard curve.

\subsection{Determination of angiotensin II levels}

Following the previously delineated experiments, blood samples were drawn from the carotid artery, collected in EDTA tubes, and centrifuged. Plasma samples were aliquoted and stored at $-20^{\circ} \mathrm{C}$ until analyzed. AngII concentrations were measured by commercially available AngII EIA kits purchased from Bertin Pharma. AngII from vehicle, captopril treated and combination of DALA and captopril treated rats were eluted by solid phase extraction using $3 \mathrm{ml}$ methanol. Once the methanol was evaporated to dryness using a stream of dry nitrogen, the ELISA was performed and the concentration of AngII present was determined by comparison to a standard curve.

\subsection{Determination of Carboxyhemoglobin (COHb) lev- els}

At the conclusion of the previously described experiments, a $1 \mathrm{ml}$ arterial blood sample was drawn from rats treated with vehicle, DALA, captopril and combination of DALA and captopril. Blood samples were analyzed for endogenous $\mathrm{CO}$ content via whole blood CO-Oximeter (Avoximeter 4000 whole blood CO-Oximeter, GMI, Inc., Ramsey, MN).

\subsection{Statistics}

Data were expressed as mean $\pm \mathrm{SE}$. Data were analyzed by repeated measure analysis of variance (ANOVA) followed by Student- 
Newman-Keuls test when appropriate (INSTAT 3). P< 0.05 was accepted as statistically significant.

\section{Results}

\subsection{Blood pressure and heart rate measurements}

We observed a dose dependent decrease in the mean arterial pressure (MAP) in rats with $2 \mathrm{mg} / \mathrm{kg}(133 \pm 2.1 \mathrm{mmHg}, \mathrm{n}=7), 8 \mathrm{mg} / \mathrm{kg}$ $(126 \pm 2.8 \mathrm{mmHg}, \mathrm{n}=7)$ and $12 \mathrm{mg} / \mathrm{kg}(123 \pm 2.86 \mathrm{mmHg}, \mathrm{n}=7)$ captopril treatment as compared to vehicle $(120 \pm 0.84 \mathrm{mmHg}, \mathrm{n}=9)$ (Fig. 1). However, there were no significant differences in animals treated with vehicle and $12 \mathrm{mg} / \mathrm{kg}$ captopril (Fig 1). There was a significant decrease in heart rate with $12 \mathrm{mg} / \mathrm{kg}$ captopril $(\mathrm{HR}=350$ $\pm 1.44 \mathrm{BPM}$,) when compared to other treated groups. Heart rate of vehicle treated animals $(\mathrm{HR}=300 \pm 1.53)$ was lower when compared to all other treated groups. The heart rate differences in vehicle treated animals may be due to the fact that the vehicle treated group was not chronically infused with $7 \mathrm{U} / \mathrm{kg}$ insulin for 14 days (Table 1).

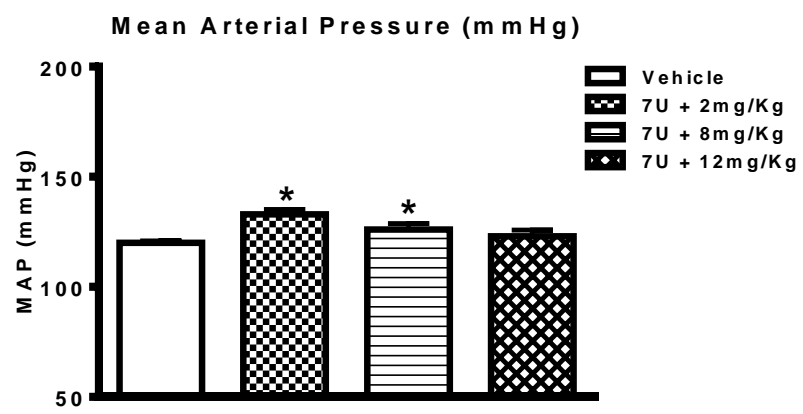

Fig. 1: Mean Arterial Pressure (MAP). MAP was measured in insulin $(7 \mathrm{U} / \mathrm{Kg})$, captopril $(2 \mathrm{mg} / \mathrm{Kg}, 8 \mathrm{mg} / \mathrm{Kg}, 12 \mathrm{mg} / \mathrm{Kg})$ and vehicle treated rats. $(* \mathrm{P}<0.05)$ Values are expressed as mean $\pm \mathrm{SE}$.

\subsection{Urine flow measurements during captopril treat- ment}

There were no significant differences in urine flow in animals treated with vehicle $(0.24 \pm 0.01 \mathrm{ml} / \mathrm{min})$ or captopril $(2 \mathrm{mg} / \mathrm{kg}=$ $0.21 \pm 0.05 \mathrm{ml} / \mathrm{min}, 8 \mathrm{mg} / \mathrm{kg}=0.26 \pm 0.02 \mathrm{ml} / \mathrm{min}, 12 \mathrm{mg} / \mathrm{kg}=0.22 \pm$ $0.03 \mathrm{ml} / \mathrm{min}$ ) (Table 1). However, the urine flow increased in all treated groups when compared to their $30 \mathrm{~min}$ control period (Table 1).

Table 1: Effects of Administration of Captopril on Urine Flow (UF), and Heart Rate (BPM).

\begin{tabular}{lcccc}
\hline & $\mathrm{N}$ & \multicolumn{2}{c}{$\begin{array}{c}\mathrm{UF} \\
(\mathrm{ml} / \mathrm{min})\end{array}$} & $\begin{array}{c}\text { Heart rate } \\
(\mathrm{BPM})\end{array}$ \\
& & 30min & $60 \mathrm{~min}$ & \\
\hline Vehicle & 9 & $0.25 \pm 0.01$ & $0.24 \pm 0.01$ & $300 \pm 1.53$ \\
$7 \mathrm{U}+2 \mathrm{mg} / \mathrm{Kg}$ & 7 & $0.16 \pm 0.05$ & $0.21 \pm 0.05$ & $361 \pm 2.18^{*}$ \\
$7 \mathrm{U}+8 \mathrm{mg} / \mathrm{Kg}$ & 7 & $0.19 \pm 0.02$ & $0.26 \pm 0.02$ & $365 \pm 0.46^{*}$ \\
$7 \mathrm{U}+12 \mathrm{mg} / \mathrm{Kg}$ & 7 & $0.16 \pm 0.02$ & $0.22 \pm 0.03$ & $350 \pm 1.44^{*}$ \\
\hline
\end{tabular}

There were no significant differences in urine flow in animals treated with various doses of captopril $(2 \mathrm{mg} / \mathrm{kg}=0.21 \pm 0.05$ $\mathrm{ml} / \mathrm{min}, 8 \mathrm{mg} / \mathrm{kg}=0.26 \pm 0.02 \mathrm{ml} / \mathrm{min}, 12 \mathrm{mg} / \mathrm{kg}=0.22 \pm 0.03$ $\mathrm{ml} / \mathrm{min})$ as compared to vehicle $(0.24 \pm 0.01 \mathrm{ml} / \mathrm{min})$. However, the urine flow increased in all treated groups when compared to their $30 \mathrm{~min}$ control period $(* \mathrm{P}<0.05)$. Values are expressed as mean \pm SE.

\subsection{Hemodynamic function measurements}

Following the previously described experiments, subsets of animals were again pretreated chronically for 2 weeks with $7 \mathrm{U} / \mathrm{Kg}$ insulin, anesthetized, and treated with vehicle (stock solution; $\mathrm{n}=9)$, DALA ( $80 \mu \mathrm{g} / \mathrm{kg} ; \mathrm{IV} ; \mathrm{n}=9)$, captopril $(12 \mathrm{mg} / \mathrm{kg} ; \mathrm{IV} ; \mathrm{n}=8)$ or a combination of DALA $(80 \mu \mathrm{g} / \mathrm{kg})$ and captopril $(12 \mathrm{mg} / \mathrm{kg} ; \mathrm{n}=8)$, during the treatment period. We observed that captopril $(112 \pm 3.17 \mathrm{mmHg})$ and DALA + CAP $(115 \pm 2.86 \mathrm{mmHg})$ significantly reduced the MAP when compared to DALA (MAP= $126 \pm 0.44)$ treated rats. There were no significant differences between DALA+CAP and vehicle $(\mathrm{MAP}=120 \pm 0.84 \mathrm{mmHg}$ ) and captopril and DALA + CAP treatments (Fig. 2). There were no significant differences in heart rate between the treatment groups (Table $2)$. However, the heart rate of vehicle $(\mathrm{HR}=300 \pm 1.53 \mathrm{BPM})$ treated animals was lower when compared to other treated groups (Table 2).

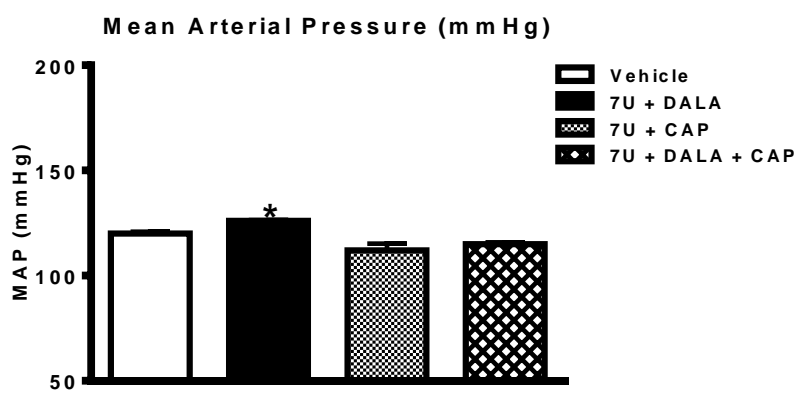

Fig. 2: Mean Arterial Pressure (MAP). MAP was measured in insulin $(7 \mathrm{U} / \mathrm{Kg})+$ DALA $(80 \mu \mathrm{g} / \mathrm{Kg})$, insulin + captopril $(12 \mathrm{mg} / \mathrm{Kg})$, insulin + DALA + captopril and vehicle treated rats. $\left({ }^{*} \mathrm{P}<0.05\right)$ Values are expressed as mean $\pm \mathrm{SE}$.

Table 2: Effects of Captopril $(12 \mathrm{mg} / \mathrm{Kg})$ and DALA $(80 \mu \mathrm{g} / \mathrm{Kg})$ On Urine Flow (UF) and Heart Rate (HR).

\begin{tabular}{|c|c|c|c|c|}
\hline & \multirow[t]{2}{*}{$\mathrm{N}$} & \multicolumn{2}{|c|}{$\begin{array}{c}\text { UF } \\
(\mathrm{ml} / \mathrm{min})\end{array}$} & \multirow[t]{2}{*}{$\begin{array}{c}\text { Heart rate } \\
\text { (BPM) }\end{array}$} \\
\hline & & $30 \mathrm{~min}$ & $60 \mathrm{~min}$ & \\
\hline Vehicle & 9 & $0.25 \pm 0.01$ & $0.24 \pm 0.01$ & $300 \pm 1.5$ \\
\hline $7 \mathrm{U}+$ DALA & 9 & $0.43 \pm 0.03$ & $0.51 \pm 0.05$ & $340 \pm 3.1$ \\
\hline $7 \mathrm{U}+\mathrm{CAP}$ & 8 & $0.36 \pm 0.04$ & $0.51 \pm 0.11$ & $346 \pm 4.1$ \\
\hline $\begin{array}{l}\text { 7U+ DALA+ } \\
\text { CAP }\end{array}$ & 8 & $0.39 \pm 0.01$ & $0.49 \pm 0.01$ & $340 \pm 7.2$ \\
\hline
\end{tabular}

There were no significant differences in urine flow in animals treated with DALA $(0.51 \pm 0.05 \mathrm{ml} / \mathrm{min})$, captopril $(0.51 \pm 0.11$ $\mathrm{ml} / \mathrm{min})$ and DALA+CAP $(0.49 \pm 0.01 \mathrm{ml} / \mathrm{min})$. However, the urine flow increased in all treated groups when compared to their $30 \mathrm{~min}$ control $(* \mathrm{P}<0.05)$. Values are expressed as mean $\pm \mathrm{SE}$.

\subsection{Urine flow and renal functional measurements dur- ing heme Oxygenase induction}

We observed no significant differences in urine flow in animals treated with DALA $(0.51 \pm 0.05 \mathrm{ml} / \mathrm{min})$, captopril $(0.51 \pm 0.11$ $\mathrm{ml} / \mathrm{min})$ and DALA+CAP $(0.49 \pm 0.01 \mathrm{ml} / \mathrm{min})$. However, the urine flow increased in all treatment groups when compared to their 30 min control periods (Table 2). There was a significant decrease in glomerular filtration rate and sodium excretion during captopril $(1.24 \pm 0.13 \mathrm{ml} / \mathrm{min})$ and DALA+CAP $(1.17 \pm 0.06 \mathrm{ml} / \mathrm{min})$ (Table $3)$. However, there were no significant differences in potassium excretion or renal blood flow (Table 3 ).

Table 3: Effects of Captopril $(12 \mathrm{mg} / \mathrm{Kg})$ and DALA $(80 \mu \mathrm{g} / \mathrm{Kg})$ on Glomerular Filtration Rate (GFR), Sodium Excretion $\left(\mathrm{U}_{\mathrm{Na}} \mathrm{V}\right)$, Urinary Potassium $\left(\mathrm{U}_{\mathrm{K}} \mathrm{V}\right)$, and Renal Blood Flow ( $\left.\mathrm{ml} / \mathrm{min} / \mathrm{gm}\right)$.

\begin{tabular}{lccccc}
\hline & $\mathrm{N}$ & $\begin{array}{c}\mathrm{GFR} \\
(\mathrm{ml} / \mathrm{min})\end{array}$ & $\begin{array}{c}\mathrm{U}_{\mathrm{Na}} \mathrm{V} \\
(\mu \mathrm{mol} / \mathrm{min})\end{array}$ & $\begin{array}{c}\mathrm{U}_{\mathrm{K}} \mathrm{V} \\
(\mu \mathrm{mol} / \mathrm{min})\end{array}$ & $\begin{array}{c}\mathrm{RBF} \\
(\mathrm{ml} / \mathrm{min} / \mathrm{gm})\end{array}$ \\
\hline $\begin{array}{l}\text { Vehicle } \\
\text { 7U+ }\end{array}$ & 9 & $1.72 \pm 0.04$ & $0.62 \pm 0.07$ & $0.42 \pm 0.06$ & $3.84 \pm 0.14$ \\
DALA & 9 & $1.82 \pm 0.26$ & $0.99 \pm 0.10$ & $0.45 \pm 0.07$ & $3.96 \pm 0.31$ \\
$\begin{array}{l}\text { 7U+CAP } \\
\text { 7U+ }\end{array}$ & 8 & $1.24 \pm 0.13^{*}$ & $0.37 \pm 0.04^{*}$ & $0.47 \pm 0.08$ & $3.50 \pm 0.61$ \\
$\begin{array}{l}\text { DALA+ } \\
\text { CAP }\end{array}$ & 8 & $1.17 \pm 0.06^{*}$ & $0.47 \pm 0.08^{*}$ & $0.48 \pm 0.03$ & $3.53 \pm 0.37$ \\
\hline
\end{tabular}




\subsection{Angiotensin II levels}

Enzyme immune assay was performed on eluted plasma; there was a significant increase in AngII concentration in animals treated with DALA $(90.9 \pm 1.05 \mathrm{pg} / \mathrm{ml})$ when compared to animals treated with vehicle $(52.5 \pm 5.07 \mathrm{pg} / \mathrm{ml})$. Animals treated with captopril and DALA+CAP had a significant decrease in AngII levels (Captopril: $36.2 \pm 1.23 \mathrm{pg} / \mathrm{ml}$; DALA+CAP: $54.4 \pm 1.25 \mathrm{pg} / \mathrm{ml}$ ) when compared to DALA treated rats. There were no significant differences between vehicle and DALA+CAP treatments. However captopril treatment reduced the AngII concentration significantly when compared to vehicle (Figure 3).

Angll Concentration (pg/m I)

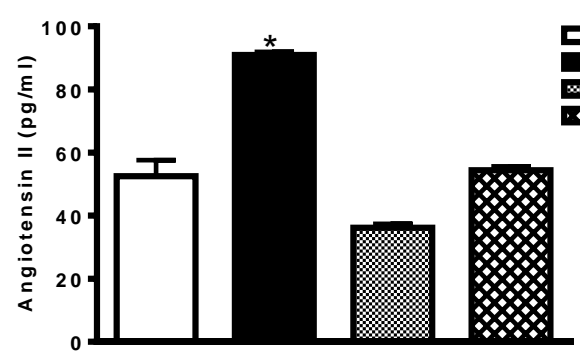

Fig. 3: Angiotensin II (AngII). AngII levels were measured in insulin $(7 \mathrm{U} / \mathrm{Kg})+$ DALA $(80 \mu \mathrm{g} / \mathrm{Kg})$, insulin + captopril $(12 \mathrm{mg} / \mathrm{Kg})$, insulin + DALA + captopril and vehicle treated rats. $(* \mathrm{P}<0.05)$ Values are expressed as mean $\pm \mathrm{SE}$.

\subsection{Heme Oxygenase levels}

ELISA was performed on the harvested hearts and kidneys, HO-1 concentration was significantly higher in animals treated with DALA (Heart: $0.7 \pm 0.01 \mathrm{ng} / \mathrm{ml}$, kidney: $0.67 \pm 0.02 \mathrm{ng} / \mathrm{ml}$ ) when compared to vehicle treated rats (Heart: $0.43 \pm 0.01 \mathrm{ng} / \mathrm{ml}$, kidney: $0.25 \pm 0.01 \mathrm{ng} / \mathrm{ml}$ ). Treatment with captopril (Heart: $0.39 \pm 0.02$ $\mathrm{ng} / \mathrm{ml}$, kidney: $0.54 \pm 0.03 \mathrm{ng} / \mathrm{ml}$ ) and DALA+CAP (Heart: $0.44 \pm$ $0.02 \mathrm{ng} / \mathrm{ml}$, kidney: $0.52 \pm 0.03 \mathrm{ng} / \mathrm{ml}$ ) decreased the HO- 1 concentration. However, there were no significant differences between HO-1 concentrations of hearts and kidneys in animals treated with captopril and DALA+CAP (Figure 4).

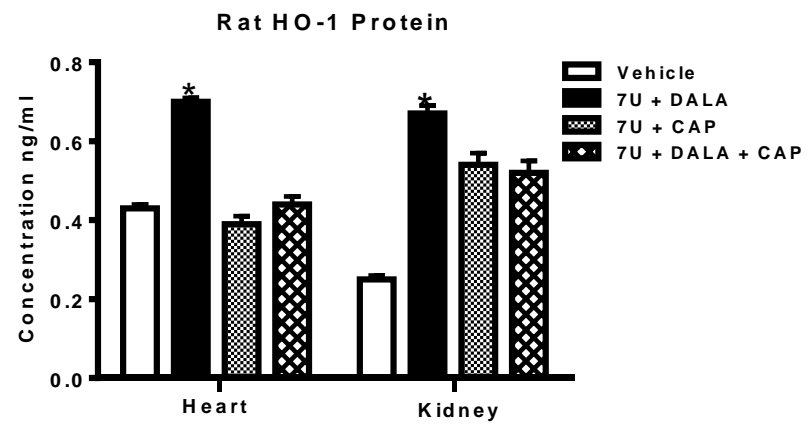

Fig. 4: Heme Oxygenase 1 (HO-1). HO-1 levels were measured in hearts and kidneys from insulin $(7 \mathrm{U} / \mathrm{Kg})+$ DALA $(80 \mu \mathrm{g} / \mathrm{Kg})$, insulin + captopril $(12 \mathrm{mg} / \mathrm{Kg})$, insulin + DALA + captopril and vehicle treated rats. $(* \mathrm{P}<0.05)$ Values are expressed as mean $\pm \mathrm{SE}$.

\subsection{Carboxyhemoglobin levels}

Treatment with DALA $(12.92 \pm 0.38 \%)$ produced a significant increase in carboxyhemoglobin $(\mathrm{COHb})$ levels as compared to vehicle $(0.05 \pm 0.04 \%)$ treated rats. Acute administration of captopril $(3.32 \pm 0.37 \%)$ and DALA + CAP $(4.1 \pm 0.30 \%)$ produced a significant decrease in $\mathrm{COHb}$ levels as compared to DALA treated rats. However, no significant differences were observed between the captopril and DALA+CAP treated groups (Figure 5).

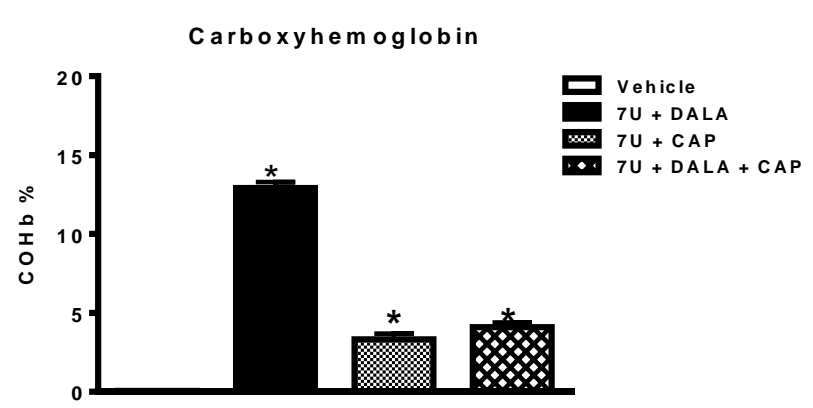

Fig. 5: Carboxyhemoglobin (COHb). $\mathrm{COHb}$ levels were measured in insulin $(7 \mathrm{u} / \mathrm{Kg})+$ Dala $(80 \mu \mathrm{g} / \mathrm{Kg})$, insulin + captopril $(12 \mathrm{mg} / \mathrm{Kg})$, insulin + DALA + captopril and vehicle treated rats. $(* \mathrm{P}<0.05)$ Values are expressed as mean $\pm \mathrm{SE}$.

\section{Discussion}

The current study demonstrates that administration of captopril decreases the mean arterial pressure (MAP) in chronic hypoglycemic hypertensive rats and decreases the HO-1 concentration by blocking the conversion of AngI to AngII which in turn decreases the levels of circulating AngII. Therefore, a reduction in circulating AngII in the current study inhibited the observed hypertension produced by RIIH.

Previous studies done in our lab demonstrated that subcutaneous administration of chronic insulin injections and/or hypoglycemia increase HO-1 levels and promotes hypertension via an elevation in endogenous carbon monoxide (CO) (Quadri et al. 2014). Many studies have documented that AngII induces HO-1 in numerous tissues; notably in vascular, cardiac, and renal (Haugen et al. 2000, Ishizaka et al. 2000, Ishizaka et al. 2002). Expression of HO-1 in aortic adventitial and endothelial cells has been demonstrated to be markedly increased in rats with AngII-induced hypertension, and treatment with AT 1 receptor antagonist (losartan), blocks the upregulation of HO-1 expression (Ishizaka et al. 1997). It has also been documented that AngII induces renal oxidative stress and HO activity which is caused by upregulation of HO-1 in renal proximal tubules (Haugen et al. 2000). In a rat model of radiation induced nephropathy, elevated glomerular HO-1 expression can be prevented by treatment with AT1 receptor antagonists, indicating that AngII may be a mediator of HO-1 induction (Datta et al. 2006).

A dose dependent decrease in MAP was observed in RIIH animals during treatment with captopril and DALA+CAP. The current study demonstrates that hypertension during severe hypoglycemic episodes may be attributed to increased levels of AngII which in turn upregulates expression of HO-1 (Haugen et al. 2000, Ishizaka et al. 2000, Ishizaka et al. 2002). It has been documented that induction of HO-1 will produce an increase in endogenous $\mathrm{CO}$ levels. High levels of CO promote vasoconstriction potentially leading to hypertension (Thorup et al. 1999). AngII is a potent vasoconstrictor and could also contribute to hypertension by increasing superoxide production (Rajagopalan et al. 1996). We used captopril because it is an angiotensin converting enzyme (ACE) inhibitor and captopril is currently used in the management of hypertension in humans. Therefore, these results would be more consistent with what's observed in hypertensive patients. Previous studies have observed no change in blood pressure during insulin pretreatment (Johansson et al. 2008) and a decrease in blood pressure during heme induction (Botros et al. 2005). Differences in previous studies could be attributed to the class, dose and/or type of administered agent in the study. The current study used delta aminolevulinic acid (DALA) to drive CO formation as it has been demonstrated in our lab that administration of low dose DALA (80 $\mu \mathrm{mol} / \mathrm{kg}$; IV) increases the expired $\mathrm{CO}$ and HO-1 levels in animals (Quadri et al. 2013). Therefore, one could reasonably argue that DALA, which is a substrate of heme, would promote an increase in HO-1 activity.

The current data supports the hypothesis that AngII is elevated in recurrent hypoglycemic rats and treatment with captopril helps in 
reducing the hypertensive effect. The data demonstrates that treatment with captopril and DALA+CAP significantly reduces circulating AngII levels in blood and also reduces the HO-1 concentration in both heart and kidney. Animals treated with DALA were observed to have a significant increase in AngII when compared to vehicle. Therefore, in the current study where RIIH was observed to produce a significant increase in AngII which lead to an induction in $\mathrm{HO}-1$ and a significant increase in endogenous $\mathrm{CO}$; one could conclude that blockade of AngII resulted in a reduction in HO activity.

In summary, the present study demonstrates that RIIH promotes hypertension via an induction in AngII levels. Captopril treatment resulted in a decrease in circulating AngII levels and also HO-1 levels and lowered the blood pressure. These findings suggest that hypoglycemia and/or insulin increases AngII levels promoting an increase in $\mathrm{HO}-1$ leading to $\mathrm{CO}$ mediated vasoconstriction and ultimately hypertension.

\section{References}

[1] Briscoe VJ, Tate DB \& Davis SN (2007) Type 1 diabetes exercise and hypoglycemia. Appl Physiol Nutr Metab 32, 573-582.

[2] Hoffman RP (2007) Sympathetic mechanism of hypoglycemic counter regulation. Curr Diabetes Rev 3, 185-193.

[3] Fisher BM, Gillen G, Dargie HJ, Inglis GC \& Frier BM (1987) The effects of insulin-induced hypoglycaemia on cardiovascular function in normal man: studies using radionuclide ventriculography. Diabetologia 30, 841-845.

[4] Fisher BM, Gillen G, Hepburn DA, Dargie HJ \& Frier BM (1990) Cardiac responses to acute insulin-induced hypoglycemia in humans. Am J Physiol 258, H1775-9.

[5] Das Evcimen N \& King GL (2007) The role of protein kinase C activation and the vascular complications of diabetes. Pharmacol Res 55, 498-510.

[6] Fukami K, Yamagishi S, Ueda S \& Okuda S (2007) Novel therapeutic targets for diabetic nephropathy. Endocr Metab Immune Disord Drug Targets 7, 83-92.

[7] Eadington DW, Frier BM \& Swainson CP (1994) Renal tubular responses to low-dose infusion of angiotensin II in type 1 diabetes mellitus; relation to chronic glycaemic control. Nephrol Dial Transplant 9, 1264-1270.

[8] Harrison-Bernard LM, Imig JD \& Carmines PK (2002) Renal AT1 receptor protein expression during the early stage of diabetes mellitus. Int J Exp Diabetes Res 3, 97-108.

[9] Sochett EB, Cherney DZ, Curtis JR, Dekker MG, Scholey JW \& Miller JA (2006) Impact of renin angiotensin system modulation on the hyperfiltration state in type 1 diabetes $J$ Am Soc Nephrol 17, 17039 .

[10]Brands MW \& Fitzgerald SM (2002) Blood pressure control early in diabetes: a balance between angiotensin II and nitric oxide. Clin Exp Pharmacol Physiol 29, 127-31.

[11]Bank AJ, Kelly AS, Thelen AM, Kaiser DR \& Gonzalez-Campoy JM (2007) Effects of carvedilol versus metoprolol on endothelial function and oxidative stress in patients with type 2 diabetes mellitus. Am J Hypertens 20, 777-83.

[12]Johnson RA, Lavesa M, Askari B, Abraham NG \& Nasjletti A (1995) A heme oxygenase product, presumably carbon monoxide, mediates a vasodepressor function in rats. Hypertension 25, 166-9.

[13]Johnson FK, Terran FJ, Prieto-Carrasquero M \& Johnson RA (2002) Vascular effects of an inhibitor of heme oxygenase are enhanced in the absence of nitric oxide. Am J Hypertens 15, 1074-1080.

[14]Maines MD (1997) The heme oxygenase system: a regulator of second messenger gases. Anпu Rev Pharmacol Toxicol 37, 517-54.

[15]Jackson KE, Jackson DW, Quadri S, Reitzell MJ \& Navar LG (2011) Inhibition of heme oxygenase augments tubular sodium reabsorption. Am J Physiol Renal Physiol 300, F941-F946.

[16] Aizawa $\mathrm{T}$, Ishizaka N, Taguchi J, Nagai R, Mori I, Tang SS, Ingelfinger JR \& Ohno M (2000) Heme oxygenase-1 is upregulated in the kidney of angiotensin II-induced hypertensive rats : possible role in renoprotection. Hypertension 35, 800-6.

[17]Haugen EN, Croatt AJ \& Nath KA (2000) Angiotensin II induces renal oxidant stress in vivo and heme oxygenase-1 in vivo and in vitro. Kidney Int 58, 144-52.

[18] Quan S, Yang L, Shnouda S, Schwartzman ML, Nasjletti A, Goodman AI \& Abraham NG (2004) Expression of human heme oxygenase-1 in the thick ascending limb attenuates angiotensin II-mediated increase in oxidative injury. Kidney Int 65, 1628-39.
[19]Hu Y, Ma N, Yang M \& Semba R (1998) Expression and distribution of heme oxygenase-2 mRNA and protein in rat kidney. $J$ Histochem Cytochem 46, 249-56.

[20] Grundemar L, Johansson MB, Ekelund M \& Högestätt ED (1995) Haem oxygenase activity in blood vessel homogenates as measured by carbon monoxide production. Acta Physiol Scand 153, 203-4.

[21]Sammut IA, Foresti R, Clark JE, Exon DJ, Vesely MJ, Sarathchandra P, Green CJ \& Motterlini R (1998) Carbon monoxide is a major contributor to the regulation of vascular tone in aortas expressing high levels of haeme oxygenase-1. Br J Pharmacol 125, 1437-44.

[22]Ferrándiz ML \& Devesa I (2008) Inducers of heme oxygenase-1. Curr Pharm Des 14, 473-86.

[23]Johnson FK, Durante W, Peyton KJ \& Johnson RA (2004) Heme oxygenase-mediated endothelial dysfunction in DOCA-salt, but not in spontaneously hypertensive, rat arterioles. Am J Physiol Heart Circ Physiol 286, H1681-7.

[24] Ishizaka N, Aizawa T, Mori I, Taguchi J, Yazaki Y, Nagai R \& Ohno M (2000) Heme oxygenase-1 is upregulated in the rat heart in response to chronic administration of angiotensin II. Am J Physiol Heart Circ Physiol 279, H672-8.

[25]Quadri S, Prathipati P, Jackson DW \& Jackson KE (2014) Hemodynamic consequences of recurrent insulin-induced hypoglycaemia. Clin Exp Pharmacol Physiol 41, 81-8.

[26]Botros FT, Olszanecki R, Prieto-Carrasquero MC, Goodman AL, Navar LG \& Abraham NG (2007) Induction of heme oxygenase-1 in renovascular hypertension is associated with inhibition of apoptosis. Cell Mol Biol 53, 51-60.

[27]Freidja ML, Toutain B, Caillon A, Desquiret V, Lambert D, Loufrani L, Procaccio V \& Henrion D (2011) Heme oxygenase 1 is differentially involved in blood flow-dependent arterial remodeling: role of inflammation, oxidative stress, and nitric oxide. Hypertension $58,225-31$

[28]Li P, Jiang H, Yang L, Quan S, Dinocca S, Rodriguez F, Abraham NG \& Nasjletti A (2004) Angiotensin II induces carbon monoxide production in the perfused kidney: relationship to protein kinase C activation. Am J Physiol Renal Physiol 287, F914-20.

[29]Jadhav A, Torlakovic E \& Ndisang JF (2008) Interaction among heme oxygenase, nuclear factor-kappaB, and transcription activating factors in cardiac hypertrophy in hypertension. Hypertension 52, 910-7.

[30]Ndisang JF, Zhao W \& Wang R (2002) Selective regulation of blood pressure by heme oxygenase-1 in hypertension. Hypertension 40, 31521.

[31]Teran FJ, Johnson RA, Stevenson BK, Peyton KJ, Jackson KE, Appleton SD, Durante W \& Johnson FK (2005) Heme oxygenasederived carbon monoxide promotes arteriolar endothelial dysfunction and contributes to salt-induced hypertension in Dahl salt-sensitive rats. Am J Physiol Regul Integr Comp Physiol 288, R615-22.

[32]Leffler CW, Parfenova H \& Jaggar JH (2011) Carbon monoxide as an endogenous vascular modulator. Am J Physiol Heart Circ Physiol 301, $\mathrm{H} 1-\mathrm{H} 11$.

[33]Marazioti A, Bucci M, Coletta C, Vellecco V, Baskaran P, Szabó C, Cirino G, Marques AR, Guerreiro B, Gonçalves AM, Seixas JD, Beuve A, Romão CC \& Papapetropoulos A (2011) Inhibition of nitric oxide-stimulated vasorelaxation by carbon monoxide-releasing molecules. Arterioscler Thromb Vasc Biol 31, 2570-6.

[34]Paranjape SA \& Briski KP (2005) Recurrent insulin-induced hypoglycemia causes site-specific patterns of habituation or amplification of CNS neuronal genomic activation. Neuroscience 130, 957-70.

[35]Ishizaka N, Aizawa T, Mori I, Taguchi J, Yazaki Y, Nagai R \& Ohno M (2000) Heme oxygenase-1 is upregulated in the rat heart in response to chronic administration of angiotensin II. Am J Physiol Heart Circ Physiol 279, H672-8.

[36]Ishizaka N, Aizawa T, Ohno M, Usui Si S, Mori I, Tang SS, Ingelfinger JR, Kimura S \& Nagai R (2002) Regulation and localization of HSP70 and HSP25 in the kidney of rats undergoing long-term administration of angiotensin II. Hypertension 39, 122-8.

[37]Ishizaka N, Leon HD, Laursen JB, Fukui T, Wilcox JN, Keulenaer GD, Greindling KK \& Alexander RW (1997) Angiotensin II-induced hypertension increases heme oxygenase-1 expression in rat aorta. Circulation 96, 1932-1929.

[38]Datta PK, Dhupar S \& Lianos EA (2006) Regulatory effects of inducible nitric oxide synthase on cyclooxygenase- 2 and heme oxygenase-1 expression in experimental glomerulonephritis. Nephrol Dial Transplant 21, 51-57.

[39]Thorup C, Jones CL, Gross SS, Moore LC \& Goligorsky MS (1999) Carbon monoxide induces vasodilation and nitric oxide release but suppresses endothelial NOS. Am J Physiol 277, F882-9.

[40]Rajagopalan S, Kurz S, Münzel T, Tarpey M, Freeman BA, Griendling KK \& Harrison DG (1996) Angiotensin II-mediated hypertension in 
the rat increases vascular superoxide production via membrane NADH/NADPH oxidase activation. Contribution to alterations of vasomotor tone. J Clin Invest 97, 1916-23.

[41]Johansson ME, Anderson IJ, Alexanderson C, Skott O, Holmang A \& Bergstrom G (2008) Hyperinsulinemic rats are normotensive but sensitized to angiotensin II. Am J Regul Integr Comp Physiol 294 R1240-7.

[42]Botros FT, Schwartzman ML, Stier CT, Goodman AL \& Abraham NG (2005) Increase in heme oxygenase-1 levels ameliorates renovascular hypertension Kidney Int 68, 45-55.

[43]Quadri S, Prathipati P, Jackson DW \& Jackson KE (2013) Augmentation of heme oxygenase promotes acute angiotensin II induced hypertension. Clin Exp Med Sci 1, 21-43. 